\title{
Low German influence on the Scandinavian languages in late medieval times - some comments on loan words, word-forming, syntactic structures and names
}

\author{
INGE SÆRHEIM
}

Særheim, I. 2019. Low German influence on the Scandinavian languages in late medieval times - some comments on loan words, word-forming, syntactic structures and names. AmS-Skrifter 27, 153-161, Stavanger, ISSN 0800-0816, ISBN 978-82-7760-183-0.

There was a strong influence from the Low German language on the languages in Scandinavia in late medieval times due to the considerable economical and cultural contact and interaction between northern Germany and the Scandinavian countries in this period, especially the Hanse trade. The vocabulary was especially affected, but also the grammatical structure and names. Some place-names from south-western Norway seem to reflect Low German influence. The loans from Low German are well integrated and adjusted to the structure of the Scandinavian languages.

Inge Særheim, Department of Cultural Studies and Languages, University of Stavanger, N-4036 STAVANGER, NORWAY. E-mail: inge.saerheim@uis.no

Keywords: loan words, place names, Hanse, Scandinavian languages, Middle Low German, language contact

\section{Got synth jw! - a toast in Low German leading to murder in Telemark in 1498}

A medieval letter (diploma) from 1489 reports on a quarrel during a drinking party in Sauland, Telemark. ${ }^{1}$ In the fight following the quarrel one of the participants was killed. It started when an expression in Low German was used in a toast: Got synth jw! This has often been interpreted as 'God bless you!'. However, Jahr's suggestion that it means 'Good health to you!', is probably more likely, $c f$. the German toast Gute Gesundheit Euch and the French A votre santé. ${ }^{2}$

'Lidvord drank to Arne and said: Got synth jw! Arne answered: I am not familiar with that babble. Helge said: We must babble something. Arne answered: Let us speak our father and mother tongue, we will not become more highly respected than they [i.e. forefathers] were. We are not familiar with that language, we 'kabretta' mouths [i.e. 'cheese spread' mouths]. Let us not babble so that we babble off our neck bone. Lidvord moped and said nothing. Arne said again: We have enough words [or: Enough has been said], and we must be aware that the man might have a wounded heart. Everyone has his own things to remember.'

The quarrel ended with a murder, which is the reason why this incident and conversation was recorded. Arne was stabbed by Lidvord, who probably was a soldier and had learned the foreign language abroad.

This is, however, not the whole story about this incident. According to another diploma from 1488, ${ }^{3}$ Lidvord had half a year earlier murdered another person. His case was under investigation, and he had a so-called kongsdagsbrev or gridsbrev ('letter of mercey'), telling that he was a free man as long as his case was under investigation. During the reported incident in Sauland the farmer, Arne, was offended by the soldier, Lidvord. Arne was hit twice without being wounded by Lidvord who used his weapon (a skothyrna, i.e. 'hellebard'). This obviously started the fight.

The quarrel started with a toast in Low German. It would, however, be to go to far to say that Arne died as a martyr, defending the Norwegian language against foreign, in this case Low German, influence, even though this document apparently reflects negative attitudes and feelings towards the use of a foreign greeting. The form of 
the language used is sometimes regarded as more important than the content.

\section{Language influence}

Nowadays many English words and expressions are loaned into the Scandinavian languages, for example within computer sciences (hardware, software, $p c$ ), petroleum industry (offshore, supply, supervisor), sport (corner, team, coach), popular culture (beat, rock, country), trade and service (catering, service). Many articles and products have English names: juice, milkshake, chips, jeans, tape. Many shops, companies and restaurants also get a foreign name. English words and names do not fit well with the Norwegian grammar, neither the phonology, morphology nor spelling, e.g. words like slacks, chips, jeans and fans. For some of the words the Norwegian Language Council has suggested alternative spellings, like jus (juice), sørvis (service), keitering (catering) and teip (tape), however some of the norwegianized spellings are not used very much.

It is not widely known amongst the general public that the influence from Low German in medieval times and later was stronger than the English influence nowadays. These loans are often difficult to discover, due to the fact that they are well integrated in the grammatical system of the Scandinavian languages. Loan words from Low German are normally easy to pronounce, spell and conjugate, whereas loans from English are difficult to adjust to the language structure. This is to some extent due to the fact that the Low German loans through hundreds of years have been integrated in the grammatical structure.

It is almost impossible for Norwegians, Swedes and Danes to have a conversation in their own languages without using many loan words from Low German. According to Torp, almost a third of the words used by Norwegians in a common conversation have Low German origin. ${ }^{4}$ This has been illustrated by the following example: 'Skredderen tenkte at trøya passet, men kunden klaget og mente at plagget var kort og tøyet simpelt og grovt' (i.e. the tailor thought that the jacket would fit very well, but the customer complained and thought that the garment was short and the fabric rude and of poor quality). Only three of the sixteen different words in the Norwegian version are of Scandinavian origin, i.e. at ('that'), og ('and') and var ('was'). The remaining thirteen words are loan words from Low German. ${ }^{5}$ Even the Norwegian words for 'language', i.e. språk n., and 'thought', i.e. tanke m., come from Low German.

It is quite normal to loan words from one language to another. During language contact words change first, before the grammatical system. ${ }^{6}$ There are tens of thousands of loan words in Norwegian and in most other languages (except for Icelandic). Loan words often come with new products, ideas and phenomena, because of close contact between people, cultures and languages.? The loans often come from a culture with prestige, economically as well as cultural. The significant Low German influence on the three Scandinavian languages in late medieval times is a result of considerable cultural contact with northern Germany in this period, due to shipping and extensive trade, especially the Hanse trade.

It has been suggested that the Norwegians and Germans in late medieval times used a type of pidgin language or lingua franca (a mixed middle language) when they spoke together, ${ }^{8}$ due to significant differences between the languages. Nowadays researchers often take the view that they understood each other because of the relationship and similarities between their languages (or rather dialects), however, they had to adjust to each other when they spoke together. It has been suggested that they used a special type of semi-communication, ${ }^{9}$ or rather passive or receptive bilinguisme. ${ }^{10}$ In other words, they understood the other language (dialect), but they were not able to speak it themselves. The Germans spoke German and the Norwegians Norwegian, however they adjusted their dialects when they spoke together, and they used many words that were common in the two languages. ${ }^{11}$ Rambø uses the term receptive bilinguisme to describe the communication between Germans and Norwegians in this period. ${ }^{12}$ She underlines that the language and dialect contact situation was different within the Hanse area in northern Europe in this period.

\section{Typological change of the Scandinavian languages}

The German influence coincides with an important typological change of the Scandinavian languages in late medieval times, that is the loss of the case system and the development from a so-called synthetic to a non-synthetic language (also called a more analytical language), namely a language with less inflection and more fixed sentence structure. The influence from Middle Low German (MLG) in this period might have enforced this transition, due to the fact that this influence was very strong and the contact situation lasted for a long time. Some of the linguistic changes in this type of contact situations may be described as levelling (such as the lack of $u$-umlaut, strand instead of strond) or simplification (e.g. two genders instead of three).

The special development of the Bergen dialect might to some extent be a result of the strong influence from Low 
German. Bergen is often described as a dialect island, a situation which is quite different from other Norwegian cities, like Oslo, Trondheim and Stavanger. Among the characteristics of the Bergen dialect, differing from the surrounding dialects, which have been suggested as possible influence from Low German, ${ }^{13}$ are lack of $u$-umlaut (e.g. strand f. 'shore', not strond), schwa-sound in endings (e.g. kaste vb. 'throw', not kasta), lengthened consonant instead of vowel (venn m. 'friend', not ven), lack of $i$-umlaut in the present tense of strong verbs (kommer 'comes', not kjem), monophthongization (øge n. 'eye', Nøstet, not auga, *Naustet), two genders instead of three (Engen, Marken, Stemmemyren, Sandviken, not "Enga, "Marka etc.). However, some of these changes are most likely to have started before the arrival of the Hanse. Nesse mentions several features appearing in the Bergen dialect in the Hanse period, among them sin-genitive, te as infinitive mark, development from three to two genders and the ending - et in the past tense of weak verbs. ${ }^{14}$

\section{The sin-genitive - a syntactic structure}

A syntactic construction which was inspired from spoken Low German in late medieval times is the so-called sin-genitive, ${ }^{15}$ found in examples like mannen sin hatt ('the man's hat') and Eva si bok ('Eva's book'). This is also called garpe-genitive, which is an expression from the late 1800s. The word garp m., referring to Germans in Bergen in medieval times, has in the Norwegian dialects got a somewhat negative meaning, 'bragger'.

The sin-genitive is especially used in the dialects in West-, Mid- and North-Norway, normally referring to ownership. It is nowadays getting more and more used in the dialects in eastern Norway and in written Norwegian, especially in a less formal style. A similar possessive expression is used in (oral) Dutch, Jan zijn hoed 'Jan's hat', and in West-Frisian, Jetze syn hoed 'Jetze's hat'. Low German sin, as well as High German sein and Dutch zijn, means 'his', which in Norwegian in some cases is expressed by the pronoun $\sin$ (i.e. 'his/her own') and in other cases by hans/hennar ('his/her', i.e. belonging to another person).

\section{Word-forming}

A number of words containing word forming elements in Middle Low German were loaned into the Scandinavian languages in medieval times, words with prefixes like an-, be-, bi-, for- and unn-, and suffixes like -aktig, -bar, -heit, -inne and-makar. Some of these suffixes became productive in Norwegian, and have been used to form new words with Norwegian word stems. Especially -heit (-het) is much used. The use of word forming elements loaned from another language represents influence on the grammatical system and shows how strong the Low German influence was in this period. Several words formed with the mentioned affixes are recorded in written sources from the early fourteenth century. Examples of modern words in the Norwegian standard language bokmål formed with four important affixes are:

an-: anmode ('request, urge'), anse ('regard'), ansette ('employ'); ansikt ('face'), andakt ('devotional, prayers'), anfall ('fit, attack')

be-: begynne ('begin'), betale ('pay'), bevare ('protect, preserve'), bekjenne ('confess, admit'), bety ('mean, signify'), befale ('command'), beholde ('keep'), berette ('tell, report'), begravelse ('funeral'), begynnelse ('beginning')

for-: forlange ('demand'), forandre ('change'), forbanne ('curse'), forstå ('understand'), forkaste ('reject'), forsiktig ('careful'), forgjeves ('in vain'), forakt ('contempt'), forståelse ('understanding')

-het (-heit): rettighet ('right, privilege'), frihet ('freedom'), rettferdighet ('justice'), kjæerlighet ('love'), sannhet ('truth'), trygghet ('safety'), menighet ('congregation'), ydmykhet ('humility').

\section{Loan words from Low German in the Scandinavian languages}

Hellquist, who has studied the age and the origin of the Swedish vocabulary, gives a description of the strength of the Low German influence on Swedish. ${ }^{16}$ He states that if Gustav Vasa had not regained the country's independent position, and if the Reformation movement had not had such a strong national character as far as the language is concerned, the Swedish language might have developed into some kind of Low German. ${ }^{17}$ According to Skautrup there are more than 1500 words of Middle Low German origin in Danish, in addition to many words formed with suffixes and prefixes that were also loaned from Low German. ${ }^{18}$ Most of these words are also found in Norwegian.

Nynorskordboka (nynorsk dictionary) contains more than 90,000 words, including almost 30,000 word stems. ${ }^{19}$ Some 13,000 of the words are loan words, imported from other languages, among them 2021 from Middle Low German. ${ }^{20}$ Numerically, there are more loan words from two other languages - Latin (4089) and Greek (2120) however, a large number of the words from these two languages are scientific and technical terms, normally not used in a common conversation. Loans from Middle Low 


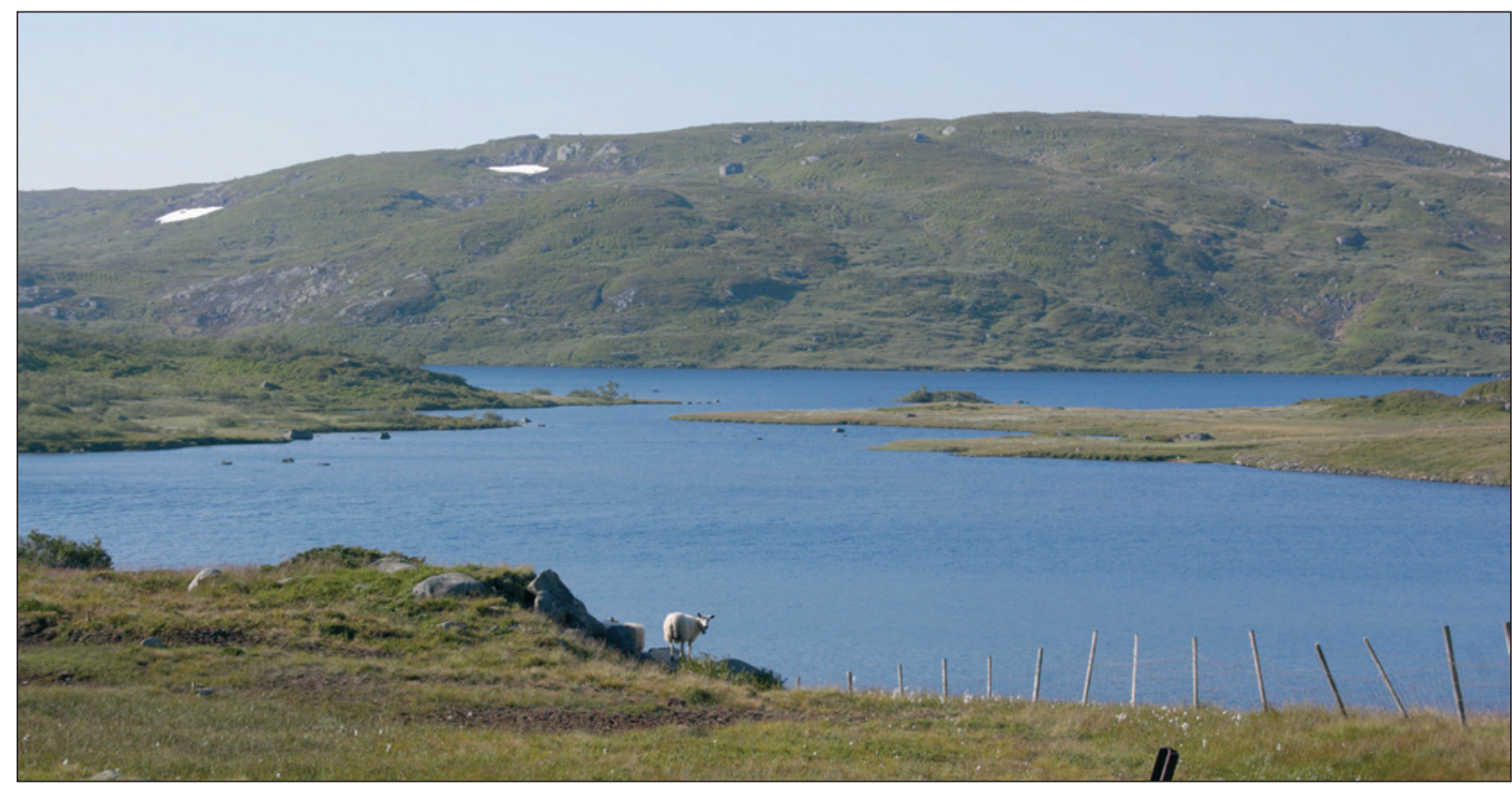

Fig. 1. The mountain plateau Hytteheia in Sirdal (Vest-Agder). The first element hytte f., which is a loan word from Low German, refers to a so-called falkehytte, a small cabin used by Dutch falcon-trappers. The word falk m. 'falcon' is also a loan word from Low German. In several Norwegian toponyms, such as Falkhaug, Falkhytta, Falkfangarfiellet, this word refers to a catch-site for falcons. The Old Norse word for 'falcon' is valr m. (photo: Inge Sarheim).

German belong to the most used words in Norwegian - in spoken dialects, as well as in the two standard languages, nynorsk and bokmål.

It may be added that nynorsk traditionally has had a more restrictive (puristic) attitude than bokmål concerning the use of words containing a Low German prefix or suffix. In spite of this Nynorskordboka includes many words formed with a Low German prefix or suffix. In Icelandic most of the loans from Middle Low German in literature from the century of the Reformation have been replaced by vernacular linguistic material. The puristic attitude has, as mentioned, also been tried in other Scandinavian languages, especially in nynorsk, but has been less successful there. Faroese is in a middle position.

In some cases a loan word from Low German competed for some time with an equivalent word in Norwegian, and later replaced it. Among the examples are straks ('right away'; ON pegar), ganske ('quite'; $c f$. ON ollungis), evig ('eternal'; ON æverðeligr, ævinligr), men ('but, however'; $\mathrm{ON}$ en), fri ('free'; ON frjáls), klaga ('complain'; ON kera), gå ('go, walk'; ON ganga), stå ('stand'; ON standa) and nåde ('grace'; ON miskunn).

The semantics (meaning) of a word in Norwegian was in some cases replaced by the semantics of the same word in Low German, for example the adjective ON rikr 'powerful' which got the new semantics 'rich' from Middle Low German, whereas ON feigr adj. 'fated to die, fey' got the meaning 'cowardly'. In some cases, the two elements of a compound appellative were translated from Low German to a Scandinavian language, as in the Norwegian kunngjera vb. ('announce') from Low German kunt maken, and innbyggjar m. ('inhabitant') from inbuwe. ${ }^{21}$

Some of the loan words came directly from Low German to Norwegian, others came through Swedish and - especially - Danish. Much influence came through daily conversation in the cities, especially with the Hanse in Bergen, and often in lower classes. Germans settled in the cities where they worked as tradesmen or craftsmen. They often got important positions due to their skills, discipline and economic situation. The loaned elements spread to the areas surrounding the cities, especially Bergen, Oslo and Tønsberg.

A number of loan words from Low German came with new products, goods, tools and professions, often linked to city life, handicraft and trade. But also words for thoughts, beliefs, feelings, qualities and new ideas were loaned. Some of the earliest loans refer to the Christian religion, the church, court life and organization.

Many words represent city life, administration, trade, shipping and travel: borgar ('citizen'), rådhus ('town hall'), menigheit ('congregation'), selskap ('party, company'), handel ('trade'), rekneskap ('account'), ballast ('ballast'), mast ('mast'), seilas ('voyage'), reise ('travel, journey'). 


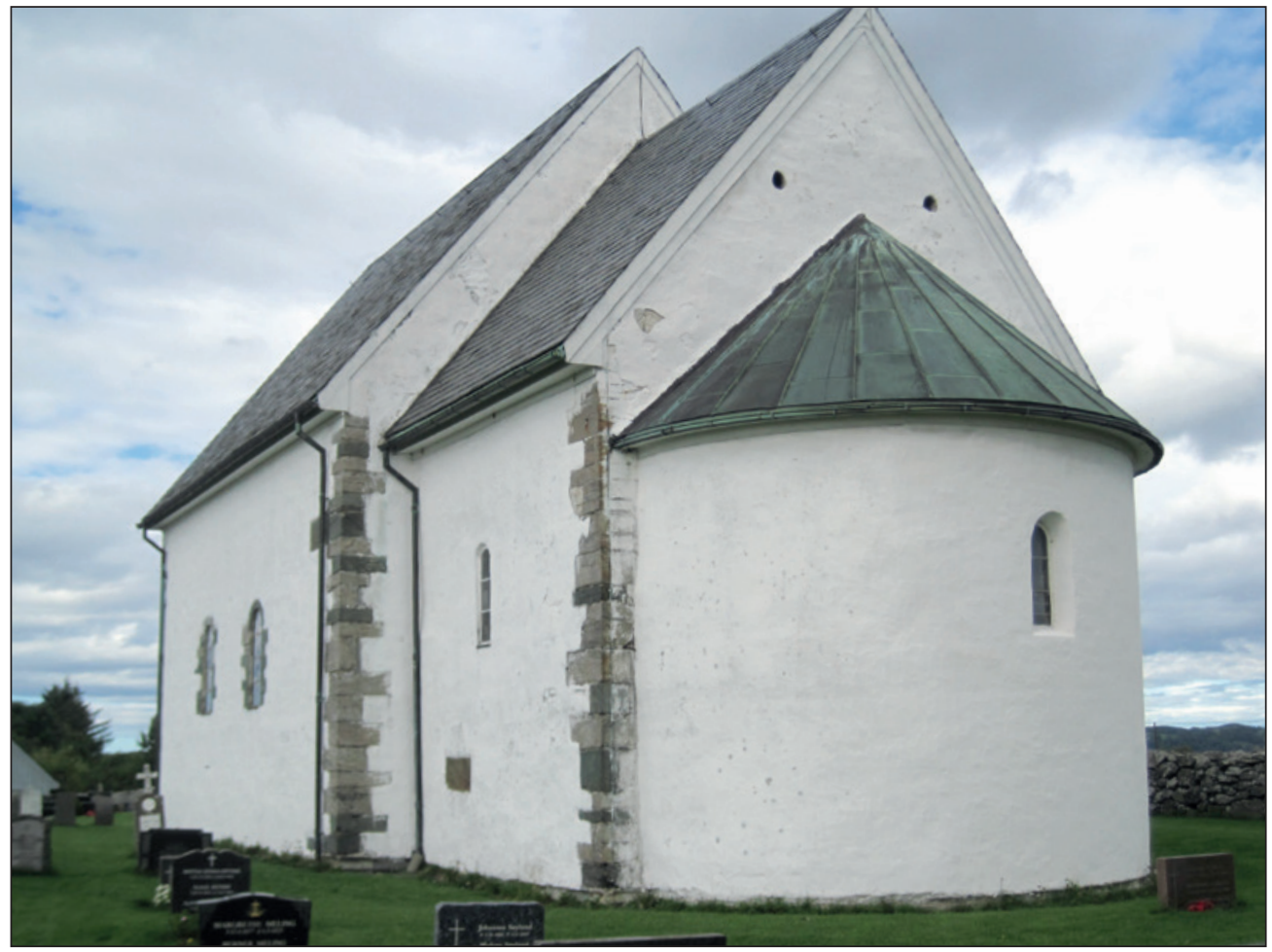

Fig. 2. The small medieval church on the island Talgje was built c. 1130-1150. The wealthy Gaute family lived here. This family had leading positions in society, and had close contact with countries around the North Sea through trade (photo: Inge Sarheim).

Some refer to the military, such as fane ('banner'), fange ('prisoner'), flukt ('escape'), kamp ('fight'), krig ('war'), ruste ('arm'), to cort life, e.g. tårn ('tower'), jakt ('hunt'), falk ('falcon') (Fig. 1), dans ('dance'), helt ('hero'), tapper ('brave'), and to the church and the society: geistlig ('clerical'), plikt ('duty'), fullmakt ('authority').

Some loan words refer to specialized functions, professions, tools, articles etc.: malar ('painter'), skomakar ('shoemaker'), slaktar ('butcher'), skipper ('sailor'), arbeid ('work, labour'), reiskap ('tool'), verktøy ('tool'), lampe ('lamp'), lykt ('torch'), glas ('glass'), papir ('paper'), svovel ('sulphur'). Words for musical instruments were loaned, orgel ('organ'), trompet ('trumpet'), basun ('trumpet, trombone'), as well as words for vegetation (fruit and vegetables), frukt ('fruit'), kirsebcer ('cherry'), pæere ('pear'), roe ('turnip'), and animals, hingst ('stallion'), kamel ('camel'), løve ('lion'), rotte ('rat').

Many loan words refer to home life and rooms, furniture and equipment in the house: kjøkken ('kitchen'), peis ('fire place'), skap ('closet'), tallerken ('plate'), gaffel ('fork'), krus ('mug'), spise ('eat'). Words for garment were loaned, tøy ('fabric, cloth'), laken ('sheet'), bukser ('trouses'), skjørt ('skirt'), strømper ('socks'), støvlar ('rubber boots'), strikka ('knit'), as well as words for personal relationship, fetter ('male cousin'), svoger ('brother-in-law'), slekt ('kin, relatives'), and personal characteristics, kjeltring ('rascal'), kjettar ('heretic').

The loan words represent different word classes, especially nouns, verbs and adjectives. However, also adverbs (e.g. forgjeves 'in vain'; ganske 'quite'; likevel 'still'; temmeleg 'quite'), conjunctions (men 'but, however') and interjections (akk) are represented. ${ }^{22}$

\section{Loan words from Low German in an inheritance document from Talgje (1366)}

One example of a medieval letter (diploma) from rural Norway containing many Low German loan words is an inheritance document written on the island Talgje in Ryfylke on 2 June $1366 .{ }^{23}$ This diploma deals with a wedding between Ingemund Utyrmesson and Holmfrid Ånundsdotter, and the valuation of the property of the bride, Holmfrid and her brother, Gunnar Ånundsson. Holmfrid and Gunnar belonged to a wealthy family living in Talgje, the so-called Gaute-family, which had leading positions in the society, and counted members that were married within the Norwegian and Danish royal family (Fig. 2). ${ }^{24}$ According to custom records from England a ship from Talgje (called Isaksbussen) visited Lynn several times in the years $1303-1306{ }^{25}$

The many words for different types of clothes and house equipment mentioned in this document from Talgje indicate that this family had close contact with countries around the North Sea through trade, including northern Germany. More than twenty evaluated articles are identified with a Low German loan word, however the diploma 
also contains loan words from French, English, Frisian and Dutch. Among the loans from Middle Low German are:

- trepete (line 12), tepete (line 18); ON tapit n., MNo tepet $\mathrm{n}$. 'blanket, carpet, bedcover', from MLG teppet, tappēt. ${ }^{26}$

- linlokum (line 14, dative), langhen lak (line 29), sparlak (line 22); ON lak n. 'blanket, bedcover', from MLG laken 'cloth (mostly of wool)'. ${ }^{27}$

- kullt (lines 29, 33); ON kult n. 'stitched quilt, cover', from MLG kolte. ${ }^{28}$

- mottul (lines 29, 33); ON mǫttul 'mantle', from MLG mantel. ${ }^{29}$

- dukar (line 49); ON dúkr '(table)cloth', from MLG $d \bar{o} k, d \bar{u} k .{ }^{30}$

- piltsens (line 99, genitive); ON pilz n. 'woollen undershirt', from MLG pils, pels. ${ }^{31}$

- strikskaut (line 62); ON strikskaut n. 'knitted headscarf', $c f$. MLG stricken vb. 'knit'. ${ }^{32}$

- kertistigga (line 43), kertihialm (line 43); ON kertistika f. 'candlestick', kertihjalmr m. 'chandelier', $c f$. MLG kerte. ${ }^{33}$

- morteel (line 45); ON mortél n. 'mortar', from MLG morter. ${ }^{34}$

- stempele (line 45); ON stempel 'stamp', from MLG stempe $(l) .{ }^{35}$

- leuiser (line 45); ON leviser, from MLG lifīisern 'armour'.36

- potter (line 46); ON pottr m. 'pot, pan', from MLG pot, put. ${ }^{37}$

- panna (line 47); ON panna f. 'pan', from MLG panne. ${ }^{38}$

- kranz (line 66); ON kranz 'wreath, garland, crown, diadem', from MLG kranz. ${ }^{39}$

- smaelt (line 66); ON smelt $\mathrm{n}$. 'enamel', from MLG smelt. ${ }^{40}$

- scelsarum (line 70); cf. OSw salser 'sause boat, gravy boat', from MLG salzēr etc. ${ }^{41}$

Several of the above mentioned examples are so-called unassimilated loans, that is words from Middle Low German used without adjustment to the phonological or morphological system of Old Norse, e.g. pilz 'woollen undershirt' and leviser 'armour. ${ }^{42}$ In the document there are also examples of loans where an Old Norse word or another morphological element from Old Norse is added, or the word is in other ways adjusted to Old Norse, e.g. strikskaut 'knitted headscarf', cf. ON skaut n. and MLG stricken vb., and serdeilis (lines 38, 48, 81 in the document), ON sérdeilis 'especially, particularly', where the final element reflects MLG dēl. ${ }^{43}$ The verb røkker (lines
100-101), ON rekkja, is used with a new semantics, 'be enough, suffice', coming from MLG.

\section{Personal names}

Personal names, especially male names, were also loaned in the Scandinavian countries from German in medieval times and later. ${ }^{44}$ In Norway, the male name Fredrik came after 1000 and Henrik (Heinrekr) before 1300. Names appearing after 1300 are Gotskalk, Hermann, Konrad, Kristian, Lodvik and Otto, and around 1400 (and later) Didrik, Engelbrekt, Henning, Kort, Kristoffer and Markvard. These names often came with German tradesmen and Germans living in Norwegian cities. Such names were given by Norwegian parents to their own children, probably due to the prestige that German citizens had in this period. The most important gateway for these names was, as one might expect, Bergen, where such names in late medieval times were used much more than other places in western Norway. ${ }^{45}$

Female names are fewer and they were less used, most likely due to the fact that there were fewer women than men among people from northern Germany living and working in the Norwegian cities; this group mainly counted tradesmen and craftsmen. Among the examples of female names are Magnhild and Valborg. ${ }^{46}$

\section{Low German influence on Norwegian place names?}

The form of some Norwegian place names seems to be a result of Low German influence. One example is the unexpected and striking form and pronunciation of the city name Bergen (Old Norse Bergvin and Bjorgvin) with toneme (i.e. pitch accent) $1 .{ }^{47}$ One would have expected toneme 2 in a vin-name with two syllables in Old Norse, like in Sandven ("Sandvin) and Løge ("Leikin). Another opinion is presented by Sørlie, ${ }^{48}$ who takes the view that the special form of the city name Bergen is normal development in the local dialect.

Another example from the same area is the place-name Det naua (Det naue), denoting a narrow sound and passage on the eastern side of the island Herdla (NorthHordaland). This name seems to be related to Middle Low German nouwe 'narrow ${ }^{49}$ and Middle Dutch nauwe with similar semantics, ${ }^{50} c f$. Dutch het Nauw van Calais, denoting a narrow part of the English Channel between Calais and Dover. ${ }^{51}$

I have suggested that the town name Kopervik on the island of Karmøy might have got its present form as a result of language contact, $c f$. spellings like Coperwijck (1588) and Coperwyck (1608) on Dutch charts, maybe influenced 
by Middle Low German kopere 'merchant, tradesman'. ${ }^{52}$ A similar name is found in eastern Norway, close to Drammen, spelled Koparwikinni in 1340, but Copperwijck in a German document from 1466 and Cop(p)erwijck on old Dutch charts. ${ }^{53}$ Hovda has suggested that the name from Drammen is composed with Old Norse kaupari m. 'tradesman, merchant', whereas the similar name from Karmøy contains the appellative kobbe m. 'seal', referring to a rock called Koparnaglen (Copernagel 1663). ${ }^{54}$ This latter suggestion does not seem likely, due to the fact that the two mentioned names from northern Karmøy are pronounced with /p/ in the northern part of the island: /"ko(:) par-/ (with /b/ in southern Karmøy: /"ko(:)bar-/). Due to the location right on the shipping lane in Karmsundet, close to the old trading centre at Avaldsnes, ${ }^{55}$ it seems more likely that the first element in the name Kopervik is Old Norse kaupari m. 'merchant, tradesman', probably influenced by Middle Low German kopere with the same semantics. A parallel from a semantic point of view is found in Eigersund in southern Rogaland, i.e. Kaupaneset on the island Eigerøy, where the first element refers to trade, $c f$. ON kaupa vb. 'to buy'.

The toponym Notta /'nots/ from Karmsundet on Karmøy might also reflect influence from northern Germany. ${ }^{56}$ This name, which presently denotes two bays on the small island Bukkøyna, probably reflects the name Notau (or Notow), which according to German and Dutch sources from the sixteenth and seventeenth centuries refers to a location situated in the Karmsund area [for the discussion on the location of Notau (Notow) and the identification of the site with Avaldsnes, see the chapters of Fyllingsnes, Ersland, as well as Elvestad \& Opedal in this volume].

Written evidence about the medieval port Notau/ Notow has been found in German archives, and this and other names from the Karmsund area appear on Dutch charts from the sixteenth and seventeenth centuries. ${ }^{57}$ Some of the local place names from this area have been interpreted and translated from Norwegian by Dutch cartographers. Hestholmen is called Perde holm and Paerde holm (charts from 1588, 1608, 1627), and Store vardane (also called Høyevarde) is referred to as Groot Warder (1663) and Gr. Warder (1714).

In old documents the place name Notau/Notow is spelled in different ways, ${ }^{58}$ e.g. Notow $(1425,1434,1477$, 1532), Notoy (1434), in nothau (1453, Latin), in notaw (1453, Latin), Noto (1453), Natouw (1454), Nothowe (1469), Nothow (1471), Notoir (1476), Notouwe (1487) and Nothaw (1584). On old maps the name is spelled Note (1539), Notuwe $(1588,1598,1608)$ and Notu $(1588,1608,1647$, $1663,1709,1714)$.
Most likely this name first denoted one of the small islands in the sound Karmsundet close to Avaldsnes, either Bukkøyna, Stutøyna, Fårøyna or Husøyna. At least two of these islands presently have a name containing a word for cattle. Stut- refers to 'bull' and Bukk- to 'billygoat'. It is tempting to interpret Får- as 'sheep' (cf. Danish får 'sheep'), however this animal is normally referred to by first elements like Sau(a)- and Smala-, whereas Får-in Norwegian toponyms often is interpreted as fure f. 'pine' or 'furrow, groove'. One of these four islands might in Old Norse have been called *Nautøy, with naut n. 'cattle' as the first element, referring to pasture for cattle. In this context it is worth noticing that piles of bones from cattle have been found on the bottom of the sea surrounding the islands. Maybe the Hanse raised and kept cattle on these islands.

The word ON naut n. 'cattle' is related to noot in Middle Dutch and $n \bar{o} z$ in Old High German, $c f$. also Middle Low German nōtil 'small cattle'. Parallels to the last element ON øy f. 'island' are Middle Low German and Middle Dutch ouwe and Old High German ouwa, with the same semantics. The Germans (and Dutch) visiting Karmøy have probably translated a Norwegian island name $\mathrm{ON}$ "Nautøy to their own languages by using forms like Notow, Notau etc., in other words a parallel to Hestholmen, called P(a)erde holm. The local name Notta /'nots/ might have developed from Low German Notau (Notow). This is, in other words, most likely an example of Low German influence on a Norwegian place-name.

In Baglarsogene (the sagas of the tribe 'baglarar') a place called við Nauteyna is mentioned, that is ON Nautey(in), referring to peace negotiations between the tribes 'baglarar' and 'birkebeinarar' in Kvitsøy in 1208. This location might be identical with the mentioned "Nautøy (i.e. Notau/Notow) by Avaldsnes. ${ }^{59}$ This seems more likely than an earlier suggestion that ON Nautey in this saga refers to the small island Nautøy in Bokn.

\section{Concluding remarks}

Linguistic material from Scandinavia, - loan words, word forming elements, syntactic structures as well as names - gives evidence of a considerable cultural contact between Scandinavia and northern Germany in medieval times, and strong influence from Middle Low German on the Scandinavian languages (and not the other way), especially on the vocabulary. Even though the influence was very strong, the Scandinavian languages survived as independent languages, due to the fact that the grammatical structure was maintained, especially the phonology and the morphology. The most important difference 
between languages like Norwegian, Swedish, Danish and Low German is not the vocabulary - the words - but the pronunciation and the conjugation, in other words the grammatical structure. The loaned elements from Low German, namely the words and affixes, were integrated and adjusted to the grammatical structure of the Scandinavian languages.

\section{Endnotes}

${ }^{1} D N 1$, no. 961

${ }^{2}$ Jahr 2012.

${ }^{3} D N 10$, no. 267.

${ }^{4}$ Torp 1982, 135f.; Torp 1988, 8.

${ }^{5} \mathrm{H} \varnothing \mathrm{dnebø} \mathrm{1971,} 41$.

${ }^{6}$ Nes 1983, 7.

${ }^{7}$ Torp and Vikør 2016, 300ff.

${ }^{8}$ Indrebø 1951, 248; Skard 1967, 126.

${ }^{9}$ Braunmüller 1994; Braunmüller 1995, 32f., $48 \mathrm{ff}$.

${ }^{10}$ Braunmüller 2012, 95ff.; Jenstad 2016, 469.

${ }^{11}$ Nesse 2002, 137.

${ }^{12}$ Rambø 2010, 375ff.

${ }^{13}$ Jahr 1995, 14ff.

${ }^{14}$ Nesse 2002, $157 f f$.

${ }^{15}$ Torp 1988; Sandøy and Nesse 2016, 75.

${ }^{16}$ Hellquist 1930.

${ }^{17}$ Ibid., 567.

${ }^{18}$ Skautrup 1947, $102 f$.

${ }^{19}$ Hovdenak et al. 2006.

${ }^{20}$ Sandøy and Östman 2004, 10.

${ }^{21}$ Torp 1982, 134.

${ }^{22}$ Torp and Vikør 2016, $300 \mathrm{ff}$.

${ }^{23} D N 4$, no. 457, 351-54.

${ }^{24}$ Koht 1951, 10; Engen 1984; Helle 1986, 119; Bjørkvik 1997, 249f.; Meling 1999.

${ }^{25}$ Helle 1975, 164f.; DN 19, nos 466, 498, 505, 508-9, 513.

${ }^{26}$ Schiller and Lübben 1878, 533; Torp 1919, 829; de Vries 1962, 582.

${ }^{27}$ Schiller and Lübben 1876, 614; Falk 1919, 56, 207, 209; Torp 1919, 360; de Vries 1962, 344.

${ }^{28}$ Schiller and Lübben 1876, 520, 593; Falk 1919, 202, 206; de Vries 1962, 333.

${ }^{29}$ Schiller and Lübben 1877, 32; Falk 1919, 178; Torp 1919, 411; de Vries 1962, 402.

${ }^{30}$ Falk 1919, 38, 210, 225; Torp 1919, 77; de Vries 1962, 87.

${ }^{31}$ Falk 1919, 146; Torp 1919, 488; de Vries 1962, 425.

${ }^{32}$ Schiller and Lübben 1878, 433; Falk 1919, 71, 101.

${ }^{33}$ Torp 1919, 275; de Vries 1962, 307.

${ }^{34}$ Schiller and Lübben 1877, 122; Torp 1919, 434.

${ }^{35}$ Schiller and Lübben 1878, 384; Torp 1919, 712.

${ }^{36}$ Simensen 1995, 65.

${ }^{37}$ Schiller and Lübben 1877, 365f.; Torp 1919, 497; de Vries $1962,427$.

${ }^{38}$ Schiller and Lübben 1877, 297; Torp 1919, 483; de Vries 1962, 423.

${ }^{39}$ Schiller and Lübben 1878, 559; Falk 1919, 116; Torp 1919, 317; de Vries 1962, 328.

${ }^{40}$ Schiller and Lübben 1878, 261; de Vries 1962, 19.
${ }^{41}$ Schiller and Lübben 1878, 17; Torp 1919, 566.

${ }^{42}$ Simensen 1995, 65.

${ }^{43}$ Ibid., 66.

${ }^{44}$ Stemshaug 1982, 40; Pettersen 1981.

${ }^{45}$ Pettersen 1981, 2.

${ }^{46}$ Særheim 2007, 444f.

${ }^{47}$ NSL, 89.

${ }^{48}$ Sørlie 1931, 164.

${ }^{49}$ Schiller and Lübben 1877, 205.

${ }^{50}$ Verdam 1932, 378.

${ }^{51}$ van Dale 1995, 1909.

${ }^{52}$ Særheim 1999, 32; Særheim 2006, 299 f.

${ }^{53}$ NG 6, 24; NG 10, 391.

${ }^{54}$ Hovda 1974, $79 f$

${ }^{55}$ Fyllingsnes 2004a, 99.

${ }^{56}$ Særheim 1998; Særheim 2006.

${ }^{57}$ Fyllingsnes 2004b, 5.

${ }^{58}$ Fyllingsnes 2004b; Særheim 2006; Særheim 2009.

${ }^{59}$ Særheim 2006, 299.

\section{References}

\section{See also list of abbreviations}

Bjørkvik, H 1997. Finnøy. Gard og æett 3. Finnøy: Finnøy Kommune.

Braunmüller, K. 1994. Semikommunikation og lingvistiske simulationsmodeller (om sprogkontakt i hansatiden), in U. B. Kotsinas and J. Helgander (eds), Dialektkontakt, språkkontakt och språkförändring i Norden. Föredrag från et forskarsymposium, 92-97. Stockholm: Stockholms Universitet.

Braunmüller, K. 1995. Forudsætninger for at overtage middelnedertyske sprogstrukturer i de skandinaviske sprog, in E. H. Jahr (ed.), Nordisk og nedertysk, 29-54. Oslo: Novus.

Braunmüller, K. 2012. Semi-communication and beyond: some results of the Hamburg Hanseatic Project (1990-1995), in L. Elmevik and E. H. Jahr (eds), Contact between Low German and Scandinavian in the Late Middle Ages. 25 years of Research, 95-111. Acta Academiae Regiae Gustavi Adolphi 121. Uppsala: Swedish Science Press.

van Dale, J. H. 1995. Groot Woordenboek der Nederlandse Taal 1-3. Utrecht: Van Dale Lexicografie. 12th edition.

Engen, S. 1984. Lagmannscetta. Gard Toreson Atta. Forsand: Forsand Kommune.

Falk, H. 1919. Altwestnordische Kleiderkunde mit besonderer Berücksichtigung der Terminologie. Videnskapsselskapets Skrifter 2, Hist.-Filos. Klasse, no. 3 (1918). Christiania: Videnskabsselskabet.

Fyllingsnes, F. 2004a. Karmøys historie 2. Kopervik: Karmøy Kommune.

Fyllingsnes, F. 2004b. Notow - hanseatane si hamn på Avaldsnes. Heimen 41, 3-21.

Helle, K. 1975. Stavanger fra våg til by. Stavanger: Stabenfeldt.

Helle, K. 1986. Då Rogaland var Rygjafylke, in E. Hovland and H. E. Næss (eds), Fra Vistehola til Ekofisk. 
Rogaland gjennom tidene 1, 75-138. Stavanger: Universitetsforlaget.

Hellquist, E. 1930. Det svenska ordförrådets ålder och ursprung 2. Lund: C. W. K. Glerups förlag.

Hovda, P. 1974. Hollandsk innverknad på namn i norske kart. Namn och Bygd 62, 78-81.

Hovdenak, M., Killingbergtrø, L., Lauvhjell, A., Nordlie, S., Rommetveit, M. and Worren, D. (eds) 2006. Nynorskordboka. Oslo: Det Norske Samlaget. 4th edition.

Hødnebø, F. 1971. Nedertyske (platt-tyske) lånord i norsk, in D. Gundersen, W. Dahl and F. Hødnebø (eds), En bok om ord, 37-41. Oslo: Universitetsforlaget.

Indrebø, G. 1951. Norsk målsoga. Bergen: John Griegs boktrykkeri.

Jahr, E. H. 1995. Nedertysk og nordisk: Språksamfunn og språkkontakt i Hansatida, in E. H. Jahr (ed.), Nordisk og nedertysk. Språkkontakt og språkutvikling i Norden $i$ seinmellomalderen, 9-28. Oslo: Novus.

Jahr, E. H. 2012. 'Got synth jw' - en middelnedertysk skålhilsen som år 1489 førte til drap på Arne? Om skålhilsenen og et seint forsvar for drapsmannen Lidvord, in U. Røyneland and H.-O. Enger (eds), Fra holtijar til holting. Språkhistoriske og språksosiologiske artikler til Arne Torp på 70-årsdagen, 173-179. Oslo: Novus.

Jenstad, T. E. 2016. Ordforrådet, in H. Sandøy (ed.), Norsk språkhistorie 1, 447-509. Oslo: Novus.

Koht, H. 1951. Det 14de hundreåret og Ogmund Finsson. Att og heim 1951, 7-12.

Meling, B. 1999. Talgje i middelalderen. Frá haug ok heiðni $1,9-13$.

Nes, O. 1983. Om nokre affiks i nynorsk - mest om -heit. Bergen: Universitetet i Bergen.

Nesse, A. 2002. Språkkontakt mellom norsk og tysk $i$ hansatidens Bergen. Oslo: Det Norske Videnskaps-Akademi.

NG - Norske Gaardnavne 1-19, O. Rygh (ed.), 1897-1936. Christiania: W. C. Fabritius \& Sønner.

NSL - Norsk stadnamnleksikon, J. Sandnes and O. Stemshaug (eds), 1997. Oslo: Det Norske Samlaget.

Pettersen, E. 1981. Personnavn $i$ Vest-Norge 1450-1550. Oslo: Novus.

Rambø, G.-R. 2010. Historiske og sosiale betingelser for språkkontakt mellom nedertysk og skandinavisk $i$ seinmiddelalderen - et bidrag til historisk språksosiologi. Oslo: Novus.

Sandøy, H. and Nesse, A. 2016. Språkendring, in H. Sandøy (ed.), Norsk språkhistorie 1, 31-99. Oslo: Novus.

Sandøy, H. and Östman, J.-O. 2004. Språkpåverkan och ansvar inom språkpolitik i Norden, in H. Sandøy and J.-O. Östman (eds), 'Det främmande' i nordisk språkpolitik. Om normering av utlänska ord, 7-29. Oslo: Novus.

Schiller, K. and Lübben, A. 1875-81. Mittelniederdeutsches Wörterbuch 1-6. Bremen: Kühtmann.

Simensen, E. 1995. Påverknaden frå mellomnedertysk på norsk i diplom frå det 14. hundreåret, in E. H. Jahr (ed.), Nordisk og nedertysk. Språkkontakt og språkutvikling $i$ Norden i seinmellomalderen, 55-80. Oslo: Novus.

Skard, V. 1967. Norsk språkhistorie til 1523. Oslo: Universitetsforlaget.

Skautrup, P. 1947. Det danske Sprogs Historie 2. Copenhagen: Gyldendal.

Stemshaug, O. 1982. Førreformatoriske namn, in O. Stemshaug (ed.), Norsk personnamnleksikon, 32-43. Oslo: Det Norske Samlaget.

Særheim, I. 1998. 'Notau...udi Karmsund'. Hansaens første handelsfaktori i Noreg?, in G. Akselberg and J. Bondevik (eds), Ord etter ord. Heidersskrift til Oddvar Nes, 242-254. Bergen: Norsk bokreidingslag.

Særheim, I. 1999. Språkkontakt i seinmellomalderen bakgrunn for lokale namn og namneformer. Frá haug ok heiðni 2, 28-33.

Særheim, I. 2006. 'Notau...udi Karmsund'. Toponyms from southwestern Norway reflecting language contact in mediaeval times, in E. Brylla and M. Wahlberg (eds), Proceedings of the 21st International Congress of Onomastic Sciences 2002, vol. 2, 289-302. Uppsala: Institutet för språk och folkminnen.

Særheim, I. 2007. Personen- und Ortsnamen, in O. E. Haugen (ed.), Altnordische Philologie. Norwegen und Island, 433-482. Berlin: de Gruyter.

Særheim, I. 2009. Lågtysk påverknad på sørvestnorske stadnamn i seinmellomalderen, in L. Mattfolk and T. Ainiala (eds), Namn och kulturella kontakter, NORNArapporter 85, 29-39. Uppsala: Norna förlaget.

Sørlie, M. 1931. Bergens bynavn. En språkhistorisk undersøkelse. Bergens historiske foreining skrifter 37, 7-221.

Torp, A. 1919. Nynorsk etymologisk ordbok. Christiania: Aschehoug \& Co.

Torp, A. 1982. Norsk og nordisk før og nå. Oslo: Universitetsforlaget.

Torp, A. 1988. Garpegenitiven - framgangsrik vestlending med kontinentale anar. Språknytt 4, 8-9, 17.

Torp, A. and Vikør, L. S. 2016. Hovuddrag i norsk språkhistorie. Oslo: Gyldendal akademisk. 4th edition.

Verdam, J. 1932. Middelnederlandsch Handwoordenboek. Den Haag: Martinus Nijhoff.

de Vries, J. 1962. Altnordisches etymologisches Wörterbuch. Leiden: Brill. 